\title{
Peran Akuntan Pendidik dalam Meningkatkan Profesionalisme Calon Akuntan
}

\author{
Aristha Purwanthari Sawitri ${ }^{1 *}$, Fauziyah ${ }^{2}$ \\ ${ }^{1,2}$ Fakultas Ekonomi Universitas PGRI Adi Buana Surabaya \\ E-mail: \\ 1aristha_p@yahoo.co.id, ${ }^{2}$ basta.fauziyah@yahoo.co.id
}

\begin{abstract}
ABSTRAK
Persaingan sumber daya manusia saat ini semakin ketat khususnya di negera Asia Tenggara (ASEAN) hal ini didukung pula dengan ditandatanganinya kesepakatan antar negara-negara ASEAN mengenai persaingan bebas yang disebut ASEAN Economic Community (AEC). Perguruan tinggi merupakan kunci utama dalam mencetak generasi bangsa khususnya calon akuntan karena calon akuntan mempunyai peran yang besar dalam perkembangan perekonomian di suatu negara serta peran akuntan pendidik diperlukan untuk mencetak calon akuntan yang berkualitas dan profesional. Peran akuntan dalam penelitian ini yaitu komitmen dan kompetensi akuntan pendidik untuk menciptakan profesionalisme calon akuntan. Definisi seseorang yang professional antara setiap individu berbeda-beda. Dimana untuk menjadi seseorang yang professional harus menguasai bidang pengetahuan (knowledge), ketrampilan (skill), dan karakteristik (Ethics). Sampel penelitian ini adalah perguruan tinggi swasta di Surabaya. Hasil penelitian ini ditemukan bahwa variabel komitmen dan kompetensi secara bersamasama berpengaruh terhadap profesionalisme calon akuntan, serta ditemukan bahwa hanya variabel komitmen berpengaruh positif secara signnifikan terhadap profesionalisme, sedangkan 33,9\% dipengaruhi oleh variabel lain di luar penelitian.
\end{abstract}

Kata Kunci: Profesionalisme, Komitmen, Kompetensi

\section{PENDAHULUAN}

Masyarakat Economi ASEAN (MEA) atau ASEAN Economic Community (AEC) merupakan kesepakatan antara negara-negara ASEAN untuk membentuk pasar bebas salah satunya dalam bidang jasa maupun tenaga kerja terampil dan sudah diberlakukan tahun 2015 . Adapun kesepakatan bersama yang telah disepakati salah satunya yaitu dibidang jasa akuntan dimana akuntan dari negara anggota ASEAN lainnya dapat masuk ke Indonesia dan bersaing dengan akuntan yang ada di Indonesia. Salah satu yang harus disiapkan oleh negara ini yaitu kompetensi dalam bidang sumber daya manusia. Kualitas sumber daya manusia yang 
berkompeten merupakan kunci utama dalam menghadapi persaingan terutama kualitas sumber daya pendidik dan calon akuntan (mahasiswa akuntansi) karena calon akuntan yang memiliki kompetensi yang tinggi akan memiliki lebih banyak kesempatan untuk memperoleh keuntungan ekonomi dalam MEA.

Kunci utama dalam menciptakan lulusan yang berkualitas pada perguruan tinggi terletak pada akuntan pendidik. Penelitian ini terbatas pada peran akuntan pendidik dilihat dari sisi komitmen dan kompetensi akuntan pendidik. Akuntan pendidik yaitu tenaga pengajar dimana di perguruan tinggi adalah dosen. Dosen yang berkompeten adalah dosen yang memiliki kemampuan dalam menyampaikan informasi terkait dengan ilmunya, professional di bidang keilmuan, mampu menggali potensi calon akuntan dan memiliki sertifikasi yang dapat menunjang kemampuan. Akuntan pendidik dituntut untuk mengembangkan kreatifitas keilmuan yang dimiliki sesuai dengan perubahan lingkungan melalui karya ilmiah, mengikuri forum internasional maupun nasional sehingga dapat mencetak calon akuntan yang unggul.

Dari latar belakang di atas peneliti tertarik untuk melakukan penelitian apakah akuntan pendidik di perguruan tinggi terutama perguruan tinggi swasta merupakan perguruan tinggi yang unggul dan memiliki akuntan pendidik yang professional, khususnya dalam peningkatan komitmen dan kompetensi profesional sehingga dapat meningkatkan profesionalisme calon akuntan yang nantinya diharapkan calon akuntan mampu bersaing dengan negara lain dalam Masyarakat Economi ASEAN (MEA).

\section{TINJAUAN PUSTAKA}

\section{Akuntan Pendidik}

Profesi akuntan adalah semua bidang pekerjaan yang menggunakan keahlian di bidang akuntansi. Dimana profesi akuntan dapat dikelompokan menjadi empat, antara lain akuntan publik (Public Accountants), akuntan internal (Internal Accountants), akuntan pemerintah (Government Accountants) dan akuntan pendidik. Definisi dari akuntan pendidik adalah akuntan yang bertugas dalam pendidikan akuntansi, melakukan penelitian dan pengembangan akuntansi, mengajar dan menyusun kurikulum pendidikan akuntansi yang ada di perguruan tinggi. Menurut Nidiya dkk (2015) dalam andriani para tenaga pendidik harus mampu memperkenalkan ekonomi kreatif pada mahasiswa dimana calon akuntan tidak hanya dibekali dengan learning to do tetapi juga pada learning to live togother dengan masyarakat negara AEC lainnya. Selain itu calon akuntan harus dibekali cara berkomunikasi yang baik, dimana mahasiswa tidak lagi berkomunikasi dalam skala regional maupun nasional tetapi juga bertaraf internasional. Selain komunikasi etika juga sangat penting dimiliki oleh mahasiswa. Menurut Andriani (2015) etika akan menuntut etos kerja generasi muda di dalam AEC sehingga etika hubungan personal dalam lingkup internasional harus dibina pada saat pembelajaran di bangku perkuliahan.

\section{Calon Akuntan}

Calon akuntan adalah mahasiswa dari perguruan tinggi yang akan menyelesaikan pendidikan di fakultas ekonomi jurusan akuntansi. Calon akuntan ini nantinya harus menjadi sumber daya yang unggul dan berperan dalam pembangunan negara. Untuk menjadi sumber daya yang unggul, calon akuntan harus berfikir kritis, dan menambah pengetahuan dan meningkatakan keterampilan. Sehingga calon akuntan dituntut untuk memiliki kemampuan hardskill dan softskill. Hal ini didukung pula Andriani (2015) dalam mahasiswa harus mampu berperan menjadi roda dalam pembangunan bangsa yaitu (1) peran sebagai kontrol sosial yaitu mahasiswa dapat berperan menjadi kontrol berjalannya pemerintah dan berperan sebagai penyalur aspirasi masyarakat kepada pemerintah, (2) mahasiswa sebagai peran bagian dari perubahan, mahasiswa sebagai kaum intelektual sangat dibutuhkan dalam perubahan bangsa. 


\section{Profesionalisme}

Profesional adalah memiliki kemampuan untuk melaksanakan tugas sesuai dengan bidangnya, melaksanakan suatu tugas atau profesi dengan menetapakan standar baku di bidang profesi yang bersangkutan dan menjalankan tugas profesinya dengan mematuhi etika profesi yang telah ditetapkan (Herawaty dan Susanto,2009). Akuntan, akademisi dan praktisi untuk menjadi profesional harus menguasai bidang pengetahuan (knowledge), ketrampilan (skill), dan karakteristik (Ethics).

\section{Komitmen}

Komitmen adalah tingkat loyalitas seseorang terhadap profesinya yang diartikan oleh individu (Mardjono, 2014). Komitmen akuntan pendidik antara lain keikutsertaan di dalam seminar,workshop, konferensi, profesionalisme dalam teamwork, peran di dalam masyarakat, independensi dan kesesuaian terhadap kode etik akuntan.

\section{Kompetensi}

Kompetensi profesional adalah kemampuan terhadap pemahaman sebuah materi pembelajaran secara mendalam dan luas (Mardjono, 2014). Kompetensi akuntan pendidik antara lain kompetensi akademik yang sesuai dengan program studi dan penguasaan materi ajar, karya ilmiah dan laporan penelitian. Dalam penelitian ini kompetensi yang digunakan adalah kompetensi pedagogik, kompetensi professional, kompetensi kepribadian dan kompetensi sosial dan indikator yang digunakan dalam penelitian ini sebanyak 7 indikator yang mengacu pada penelitian Permanasari (2014).

\section{Pengaruh Kompetensi Terhadap Profesionalisme}

Akuntan pendidik dapat menciptakan calon akuntan yang professional jika memiliki kompetensi yang baik dimana kompetensi meliputi kompetensi pedagogik, kompetensi professional, kompetensi kepribadian dan kompetensi sosial. Dengan kompetensi yang dimiliki akuntan pendidik, maka atmosfir akademik dapat berjalan dengan baik dimana calon akuntan dapat memahami apa yang telah disampaikan oleh akuntan pendidik sehingga dapat berpartisipasi aktif di dalam proses pembelajaran. Interaksi antara akuntan pendidik dan calon akuntan dapat meningkatkan kinerja calon akuntan yang dapat tercermin dari kualitas calon akuntan. Kowang (2014), Isnaini (2015), menjelaskan pula mengenai kompetensi. Adapun hipotesis dalam penelitian ini adalah :

$\mathrm{H}_{1} \quad$ : Kompetensi akuntan pendidik berpengaruh terhadap profesionalisme calon akuntan dalam menghadapi tuntutan profesionalisme di persaingan pasar bebas

\section{Pengaruh Komitmen Terhadap Profesionalisme}

Tranggono (2008) dalam penelitiannya menjelaskan bahwa komitmen merupakan loyalitas individu pada profesinya, dimana apabila seorang individu memiliki komitmen maka dapat mendorong perilaku individu tersebut untuk memiliki kinerja yang berkualitas dan menyelesaikan kewajiban atau tugas yang diberikan kepada individu tersebut untuk mencapai sebuah tujuan. Adapun hipotesis penelitian adalah :

$\mathrm{H}_{2} \quad$ : Komitmen akuntan pendidik berpengaruh terhadap profesionalime calon akuntan dalam menghadapi tuntutan profesionalisme di persaingan pasar bebas

\section{METODOLOGI PENELITIAN}

\section{Metode Pengumpulan Data}

Populasi pada penelitian ini adalah para akuntan pendidik fakultas ekonomi program studi akuntansi pada beberapa perguruan tinggi swasta di Surabaya. Sampel 
dalam penelitian ini diambil dengan menggunakan perhitungan rumus Slovin dengan batas toleransi kesalahan 5-10\%, sehingga jumlah sampel dalam penelitian ini kurang lebih 160 akuntan pendidik. Alat ukur yang digunakan dalam penelitian ini adalah kuisioner yang berbentuk skala terstruktur. Kuisioner yang digunakan adalah model kuisioner tertutup dan menggunakan skala likert yang menyediakan empat alternatif jawaban dan penyekoran, sebagai berikut:

Tabel 1

Alternatif Jawaban dan Penyekoran

\begin{tabular}{|l|l|l|}
\hline NO & Jawaban & Skor \\
\hline 1 & Sangat Tidak Setuju & 1 \\
\hline 2 & Tidak Setuju & 2 \\
\hline 3 & Ragu-Ragu & 3 \\
\hline 4 & Setuju & 4 \\
\hline 5 & Sangat Setuju & 5 \\
\hline
\end{tabular}

Jenis dan Sumber Data

Data dalam penelitiian ini adalah data primer yaitu data yang diperoleh dari jawaban kuesioner yang dibagikan kepada akuntan pendidik di Kota Surabaya.

\section{Metode Analisis Data}

Hipotesis dalam penelitian ini menggunakan analisis regresi berganda. Model persamaan regresi berganda yang digunakan dalam penelitian yaitu :

Profesionalisme $=\beta_{0}+\beta_{1} \mathrm{KOMP}+\beta_{3} \mathrm{KOMIT}+\mathrm{e}$

Dimana :

$\beta_{0} \quad=$ Konstanta

$\beta_{1,} \beta_{2}=$ Koefisien Regresi Variabel Bebas

Komp $=$ Kompetensi

Komit $=$ Komitmen

$\mathrm{e} \quad=$ Error

\section{PEMBAHASAN}

\section{Uji Asumsi Klasik}

Uji Normalitas

Berdasarkan pada tabel 2 terlihat bahwa nilai Sig. (2-tailed) sebesar 0,400 $>0.05$ dimana nilai residual terstandarisasi dinyatakan menyebar secara normal.

Tabel 2 Uji Normalitas

\begin{tabular}{|c|c|c|}
\hline \multicolumn{3}{|c|}{ One-Sample Kolmogorov-Smirnov Test } \\
\hline & & $\begin{array}{l}\text { Unstandardized } \\
\text { Residual }\end{array}$ \\
\hline \multicolumn{2}{|l|}{$\mathrm{N}$} & 76 \\
\hline \multirow[t]{2}{*}{ Normal Parameters ${ }^{\mathrm{a}, \mathrm{b}}$} & Mean & .0000000 \\
\hline & $\begin{array}{l}\text { Std. } \\
\text { Deviation }\end{array}$ & 6.4958 \\
\hline
\end{tabular}




\begin{tabular}{|c|c|c|}
\hline \multicolumn{3}{|c|}{ One-Sample Kolmogorov-Smirnov Test } \\
\hline Most Extreme Differences & Absolute & .103 \\
\hline & Positive & .103 \\
\hline & Negative & -.078 \\
\hline Kolmogorov-Smirnov Z & & .895 \\
\hline Asymp. Sig. (2-tailed) & & .400 \\
\hline
\end{tabular}

\section{Uji Linieritas}

Uji linieritas dilakukan agar diketahui hubungan dua variabel secara linier sehingga antara variabel X dan Y layak dilakukan uji regresi. Selanjutnya hasil pengujian linier adalah sebagai berikut :

Tabel 3 Uji Linieritas

\begin{tabular}{|c|c|c|c|c|c|}
\hline \multicolumn{7}{|c|}{ Model Summary $^{\text {b }}$} \\
\hline Model & $\mathrm{R}$ & R Square & $\begin{array}{c}\text { Adjusted R } \\
\text { Square }\end{array}$ & $\begin{array}{c}\text { Std. Error of } \\
\text { the Estimate }\end{array}$ & $\begin{array}{c}\text { Durbin- } \\
\text { Watson }\end{array}$ \\
\hline 1 & $.813^{\mathrm{a}}$ & .661 & .652 & 6.584 & 1.580 \\
\hline
\end{tabular}

a. Predictors: (Constant), KOMITMEN, KOMPETENSI

b. Dependent Variable: PROFESIONALISME

Dari tabel hasil uji linieritas diatas diketahui bahwa nilai DW 1.580 berada dibawah dl 1.586 Nilai signifikansi diatas dapat dikatakan bahwa antara variabel $\mathrm{X}$ dan $\mathrm{Y}$ terdapat hubungan linier yang signifikan sehingga layak dilakukan uji regresi.

\section{Uji Multikolinearitas}

Pada pengujian multikolinearitas diketahui kedua variabel independent yaitu modal sosial dan kompetensi kewirausahaan mempunyai nilai VIF sebesar 2,620<10 sehingga tidak ditemukan multikolinearitas.

Tabel 4 Uji Multikolinearitas

\begin{tabular}{|c|c|c|c|c|c|c|c|c|}
\hline \multicolumn{9}{|c|}{ Coefficients $^{\mathbf{a}}$} \\
\hline \multirow{2}{*}{\multicolumn{2}{|c|}{ Model }} & \multicolumn{2}{|c|}{$\begin{array}{l}\text { Unstandardize } \\
\text { d Coefficients }\end{array}$} & \multirow{2}{*}{$\begin{array}{c}\begin{array}{c}\text { Standardized } \\
\text { Coefficients }\end{array} \\
\text { Beta }\end{array}$} & \multirow{2}{*}{$\mathrm{t}$} & \multirow{2}{*}{ Sig. } & \multicolumn{2}{|c|}{$\begin{array}{c}\text { Collinearity } \\
\text { Statistics }\end{array}$} \\
\hline & & B & $\begin{array}{l}\text { Std. } \\
\text { Error }\end{array}$ & & & & Tolerance & VIF \\
\hline 1 & (Constant) & 34.473 & 6.942 & & 4.966 & .000 & & \\
\hline & KOMPETENSI & .033 & .054 & .067 & .607 & .546 & .382 & 2.620 \\
\hline & KOMITMEN & 1.062 & .154 & .759 & 6.885 & .000 & .382 & 2.620 \\
\hline
\end{tabular}

\section{Uji Autokorelasi}

Dari pengujian yang dilakukan, diperoleh nilai statistik Durbin-Watson (D-W) sebesar 1,580. Selanjutnya nilai tersebut akan dibandingkan dengan nilai tabel signifikansi $5 \%$, dengan jumlah observasi sebanyak $n=76$ dan jumlah variabel independen yang digunakan sebanyak $\mathrm{k}=2$, diperoleh nilai $\mathrm{d}_{\mathrm{L}}=1,586$ dan $\mathrm{d}_{\mathrm{U}}=$ 
1,688. Karena nilai $\mathrm{D}-\mathrm{W}$ lebih kecil dari $\mathrm{d}_{\mathrm{L}}$ yakni 1,580> 1,586, maka dapat dikatakan bahwa data tidak terdapat autokorelasi.

Tabel 5 Uji Autokorelasi

\begin{tabular}{|c|c|r|r|r|r|}
\hline \multicolumn{6}{|c|}{ Model Summary } \\
\hline Model & R & R Square & $\begin{array}{l}\text { Adjusted } \\
\text { R Square }\end{array}$ & $\begin{array}{l}\text { Std. Error of } \\
\text { the Estimate }\end{array}$ & $\begin{array}{r}\text { Durbin- } \\
\text { Watson }\end{array}$ \\
\hline 1 & $.813^{\mathrm{a}}$ & .661 & .652 & 6.584 & 1.580 \\
\hline
\end{tabular}

\section{Uji Heterokedastisitas}

Pengujian heterokedastisitas yang dilakukan menghasilkan titik-titik menyebar secara acak, tidak membentuk sebuah pola tertentu yang jelas, serta tersebar baik di atas maupun di bawah angka 0 pada sumbu Y. Hal ini berarti tidak terjadi heterokedastisitas pada model regresi. Gambar penyebaran titik tersebut dapat dilihat dibawah:

\section{Gambar 2 Uji Heterokedastisitas}

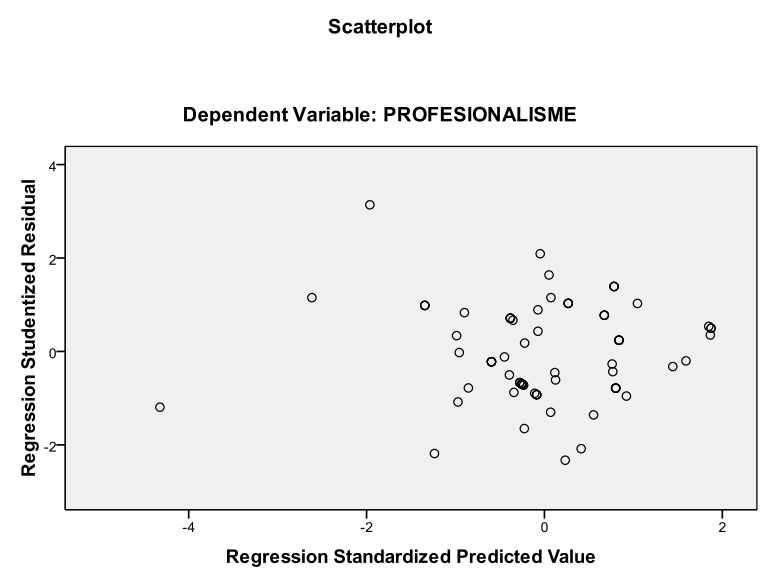

\section{Uji Regresi Linear Berganda}

Pada Uji regresi linier berganda akan diketahui pengaruh antar variabel penelitian yang meliputi Kompetensi (X1), Komitmen (X2) dan Profesionalisme (Y) sehingga digunakan model analisis regresi. Hasil uji regresi sebagai berikut:

Tabel 6 Uji Regresi Linear Berganda

\begin{tabular}{|c|c|c|c|c|c|c|c|c|}
\hline \multicolumn{9}{|c|}{ Coefficients $^{\mathrm{a}}$} \\
\hline & \multirow{2}{*}{ Model } & \multicolumn{2}{|c|}{$\begin{array}{l}\text { Unstandardized } \\
\text { Coefficients }\end{array}$} & \multirow{2}{*}{\begin{tabular}{|c}
$\begin{array}{c}\text { Standardized } \\
\text { Coefficients }\end{array}$ \\
Beta
\end{tabular}} & \multirow{2}{*}{$\mathrm{t}$} & \multirow{2}{*}{ Sig. } & \multicolumn{2}{|c|}{$\begin{array}{c}\text { Collinearity } \\
\text { Statistics }\end{array}$} \\
\hline & & B & $\begin{array}{l}\text { Std. } \\
\text { Error }\end{array}$ & & & & Tolerance & VIF \\
\hline 1 & (Constant) & 34.473 & 6.942 & & 4.966 & .000 & & \\
\hline
\end{tabular}




\begin{tabular}{|c|c|c|c|c|c|c|c|}
\hline \multicolumn{8}{|c|}{ Coefficients $^{\mathbf{a}}$} \\
\hline KOMPETENSI & .033 & .054 & .067 & .607 & .546 & .382 & 2.620 \\
\hline KOMITMEN & 1.062 & .154 & .759 & 6.885 & .000 & .382 & 2.620 \\
\hline
\end{tabular}

Pengujian regresi linier berganda yang telah dilakukan mendapatkan persamaan regresi sebagai berikut:

$$
\mathrm{Y}=34,473+0,033 \mathrm{Komp}+1,602 \mathrm{Komit}
$$

a. Nilai Konstanta $=34,473$

Nilai tersebut menunjukkan jika variabel X1 dan X2 dalam kondisi tetap atau konstan maka variabel profesionalisme (Y) sebesar 34,473 satuan.

b. Nilai $\beta_{1}=0,033$

Nilai tersebut menunjukkan tanda koefisien regresi yang positif mempunyai arti adanya pengaruh yang searah antara variabel Kompetensi (X1) dengan Profesionalisme (Y), yang artinya apabila terjadi penambahan pada variabel Kompetensi sebanyak 1 satuan maka Profesionalisme akan mengalami peningkatan sebesar 0,033 satuan dengan asumsi variabel lain tetap.

c. Nilai $\beta_{2}=1,062$

Nilai diatas menunjukkan pengaruh yang searah antara variabel Komitmen dengan variabel Profesionalisme. Lebih lanjut dapat dijelaskan jika terdapat penambahan pada variabel Komitmen sebanyak 1 satuan Profesionalisme akan mengalami peningkatan sebesar 1,062 dengan asumsi variabel lain tetap.

\section{Uji Hipotesis}

Tabel 7 Uji Hipotesis

\begin{tabular}{|c|c|r|r|c|}
\hline \multicolumn{5}{|c|}{ Model Summary $^{\mathbf{b}}$} \\
\hline Model & R & $\begin{array}{c}\text { R } \\
\text { Square }\end{array}$ & $\begin{array}{c}\text { Adjusted } \\
\text { R Square }\end{array}$ & $\begin{array}{c}\text { Std. Error of the } \\
\text { Estimate }\end{array}$ \\
\hline 1 & $.813^{\mathrm{a}}$ & .661 & .652 & 6.584 \\
\hline
\end{tabular}

a. Predictors: (Constant), KOMITMEN, KOMPETENSI

b. Dependent Variable: PROFESIONALISME

\begin{tabular}{|l|l|r|r|r|r|r|}
\hline \multicolumn{7}{|c|}{ ANOVA $^{\text {b }}$} \\
\hline \multicolumn{2}{|c|}{ Model } & $\begin{array}{c}\text { Sum of } \\
\text { Squares }\end{array}$ & df & $\begin{array}{c}\text { Mean } \\
\text { Square }\end{array}$ & F & Sig. \\
\hline \multirow{2}{*}{1} & Regression & 6173.413 & 2 & 3086.707 & 71.201 & $.000^{\mathrm{a}}$ \\
\cline { 2 - 7 } & Residual & 3164.692 & 73 & 43.35 & & \\
\cline { 2 - 7 } & Total & 9338.105 & 75 & & & \\
\hline
\end{tabular}

a. Predictors: (Constant), KOMITMEN, KOMPETENSI

b. Dependent Variable: PROFESIONALISME 


\begin{tabular}{|c|c|c|c|c|c|c|c|c|}
\hline \multicolumn{9}{|c|}{ Coefficients $^{\mathbf{a}}$} \\
\hline & \multirow{2}{*}{ Model } & \multicolumn{2}{|c|}{$\begin{array}{l}\text { Unstandardized } \\
\text { Coefficients }\end{array}$} & \multirow{2}{*}{\begin{tabular}{|c|}
$\begin{array}{c}\text { Standardize } \\
\mathrm{d} \\
\text { Coefficients }\end{array}$ \\
Beta
\end{tabular}} & \multirow[t]{2}{*}{ t } & \multirow{2}{*}{ Sig. } & \multicolumn{2}{|c|}{$\begin{array}{l}\text { Collinearity } \\
\text { Statistics }\end{array}$} \\
\hline & & B & $\begin{array}{l}\text { Std. } \\
\text { Error }\end{array}$ & & & & Tolerance & VIF \\
\hline \multirow[t]{3}{*}{1} & (Constant) & 34.473 & 6.942 & & 4.966 & .000 & & \\
\hline & KOMPETENSI & .033 & .054 & .067 & .607 & .546 & .382 & 2.620 \\
\hline & KOMITMEN & 1.062 & .154 & .759 & 6.885 & .000 & .382 & 2.620 \\
\hline
\end{tabular}

a. Dependent Variable: PROFESIONALISME

Pada tabel diatas nilai $\mathrm{F}$ hitung sebesar 71,201 dengan taraf signifikansi lebih kecil dari $0,05(0,000<0.05)$. Dengan demikian dapat disimpulkan bahwa komitmen dan kompetensi secara bersama-sama memiliki pengaruh signifikan terhadap profesionalisme

Besar hubungan antar variabel profesionalisme dengan komitmen dan kompetensi dapat dilihat dari nilai R. Nilai R sebesar 0,813 atau $81,3 \%$. Nilai $R$ square diperoleh sebesar 0,661. Hal ini berarti bahwa $66,1 \%$ profesionalisme dapat dijelaskan oleh komitmen dan kompetensi, sedangkan $33.9 \%$ lainnya dapat dijelaskan oleh variabel lainnya.

Pengujian hipotesis mengenai pengaruh variabel kompetensi terhadap profesionalisme menunjukkan nilai t hitung sebesar 0,607 dan pengaruhnya tidak signifikan karena probabilitas signifikansinya sebesar 0,546 jauh di atas 0,05 . Dengan demikian Hipotesis 1 ditolak. Dari hasil uji yang dilakukan menunjukkan bahwa kompetensi yang dimiliki oleh akuntan pendidik tidak berpengaruh terhadap profesionalisme calon akuntan. Hasil penelitian ini menunjukkan bahwa kompetensi yang dimiliki akuntan pendidik masih rendah. Akuntan pendidik tidak hanya dituntut dalam pengajaran tetapi akuntan pendidik juga dituntut dalam bidang penelitian, pengabdian dan dituntut untuk mengikuti pembaharuan yang terkait tentang perkembangan ilmu akuntansi, sehingga kemampuan dan pengetahuan yang dimiliki akuntan pendidik mengalami peningkatan untuk membantu dalam memenuhi kewajiban sebagai akuntan pendidik dan menciptakan calon akuntan yang professional. Kondisi ini dimungkinkan karena suasana atmosfer akademik yang ada di perguruan tinggi kurang berkembang dimana perguruan tinggi kurang mengakomodasi kebutuhan dosen untuk memenuhi kompetensinya dan kurangnya partisipasi mahasiswa dalam kegiatan perkuliahan. Penelitian ini mendukung penelitian Tiyanto (2010).

Berdasarkan hasil pengujian hipotesis mengenai pengaruh variabel komitmen terhadap profesionalisme menunjukkan nilai thitung sebesar 6,885 dan pengaruhnya signifikan karena probabilitas signifikansinya sebesar 0.000 jauh di bawah 0,05. Dengan demikian Hipotesis 2 diterima. Dari hasil uji yang dilakukan dapat disimpulkan bahwa akuntan pendidik dapat menjalankan peran nya atau kewajiban nya sebagai pendidik dengan berorientasi untuk menghasilkan lulusan yang professional di bidang akuntansi. Dengan adanya komitmen yang dimiliki oleh akuntan pendidik, dapat diartikan bahwa akuntan pendidik tersebut merasa 
bertanggung jawab atas peserta didiknya untuk menciptakan calon lulusan yang berkualitas / professional melalui keahlian yang telah dimiliki oleh akuntan pendidik, sehingga calon akuntan dapat bersaing di dunia kerja dan mendorong akuntan pendidik untuk melakukan peran. Penelitian ini mendukung penelitian Mardjono (2014).

\section{KESIMPULAN DAN SARAN}

Setelah melakukan pengujian, dapat disimpulkan bahwa variabel komitmen dan kompetensi secara bersama-sama berpengaruh terhadap profesionalisme calon akuntan, serta ditemukan bahwa hanya variabel komitmen berpengaruh positif secara signifikan terhadap profesionalisme, sedangkan 33,9\% dipengaruhi oleh variabel lain di luar penelitian. Keterbatasan penelitian ini adalah waktu pengambilan data, hal ini dikarenakan bersamaan dengan libur perkuliahan yang berbeda pada setiap perguruan tinggi, sehingga mempengaruhi waktu tunggu untuk pengambilan data dan analisis data, sehingga untuk peneliti berikutnya diharapkan dapat mempertimbangkan waktu penyebaran kuesioner. Keterbatasan penelitian ini adalah pengambilan data menggunakan kuesioner sehingga jawaban responden mencerminkan jawaban yang tidak sebenarnya, untuk penelitian selanjutnya disarankan untuk menambah hasil wawancara sehingga mendukung data yang digunakan dalam penelitian.

\section{REFERENSI}

Andriani, Chichi. 2015. Mahasiswa dan Perguruan Tinggi Dalam Era ASEAN Economic.Community 2015. SNEMA Padang

Herawaty dan Susanto. 2009. "Pengaruh Profesionalisme, Pengetahuan Mendeteksi Kekeliruan, dan Etika Profesi Terhadap Pertimbangan Tingkat Materialitas Akuntan Publik. Jurnal Akuntansi dan Keuangan”. Vol. 11, no. 1, mei 2009: 13-20

Isnaini, dkk. 2015. Pengaruh Kompetensi Dosen dan Fasilitas Belajar Terhadap Kepuasan Mahasiswa Pendidikan Ekonomi FKI PUNS. Jurnal Pendidikan Bisnis dan Ekonomi Vol 1 No. 2. Universitas Sebelas Maret

Long, C.S., Ibrahim, Z., \& Kowang, T.O. (2013). An Analysis on the Relationship between Lectures Competencies and Student Satisfaction. International Educations Studies, 7 (1), 37 - 46

Martadi, Indiana Farid dan Sri Suranta. 2006. Persepsi Akuntan, Mahasiswa Akuntansi, dan Karyawan Bagian Akuntansi Dipandang Dari Segi Gender Terhadap Etika Bisnis dan Profesi (S tudi Wilayah Surakarta), Simposium Nasional Akuntansi IX Padang.

Mardjono, Eny Susilowati dan Badingatus. 2014. Profesionalisme Akuntan Pendidik : Perspektif atau Triger Kualitas Lulusan Akuntansi Di Era Masyarakat Ekonomi ASEAN. Jurnal Akuntansi dan Auditing. Volume 11 No.1 November. Hal : 103 $-109$

Permanasari, Rina dan Siti. 2014. Model Hubungan Kompetensi, Profesional dan Kinerja Dosen. Jurnal Bisnis, Manajemen dan Perbankan. Vol.2 No.1 September. Universitas Muhammadiyah Sidoarjo

Sugihartono, dkk. 2007. Psikologi Pendidikan. Yogyakarta: UNY Press

Sugiyono. 2010. Metode Penelitian Bisnis : Pendekatan Kuantitatif, Kualitatif dan 
$R \& D$. Alfabeta, Bandung.

Tiyanto, Prihatin. 2010. Kompetensi Dosen Hubungannya Dengan Praktek Organisasi Perguruan Tinggi Swasta di Kopertis Wilayah VI Jawa Tengah. AKSES Jurnal Ekonomi dan Bisnis. Vol 5 No. 9 April

Tranggono dan Andi. 2008. Pengaruh Komitmen Organisasional dan Profesional Terhadap Kepuasan Kerj Auditor Dengan Motivasi Sebagai Variabel Interverning. Jurnal Bisnis dan Ekonomi. Maret Vol. 15 No. 2 Hal 80-90

Triani, dkk. 2015. Kesiapan Profesi Akuntan di Indonesia Dalam Menghadapi MEA. Syariah Paper Accounting FEB UMS.

Walgito, Bimo, 2004. Pengantar Psikologi Umum. Andi, Yogyakarta. 